\title{
BENJAMÍN JARNÉS Y FEDERICO CARLOS SAINZ DE ROBLES: BILDUNGSROMAN Y SEMINARIO
}

\author{
FERMín EZPELETA AgUILAR \\ Universidad de Zaragoza
}

\section{Novelística de internado religioso y autobiografía}

Las novelas de internados religiosos conforman en la literatura española un grupo narrativo con marcas comunes ${ }^{1}$. El protagonista de estas historias narradas es un estudiante que cursa los primeros años de enseñanza, sea dentro de un seminario o en otro internado bajo la advocación de una orden religiosa, caracterizada siempre por la ferocidad y por la inadecuación de sus maneras pedagógicas. De modo que se hace sistemática la orientación del curso narrativo hacia la coerción y extorsión que ejercen los profesores, que funcionan como un bloque de «oponentes», a través de castigos brutales que empujan al escolar protagonista hacia la aniquilación definitiva (en el caso de las novelas naturalistas) o hacia la fuerte mutilación parcial en la mayor parte de las narraciones de las primeras décadas del XX.

La primera etapa responde, en efecto, al estímulo del Naturalismo radical, con novelas poco conocidas de los escritores representativos 2 . Pero la etapa dorada

\footnotetext{
${ }^{1}$ Ver, para las novelas de internados, F. Ezpeleta, El profesor en la literatura. Pedagogía y educación en la narrativa española (1875-1939), Biblioteca Nueva, Madrid, 2006, págs. 89 y sigs. Estas páginas corresponden al capítulo tercero, «El internado religioso». Contiene bibliografía final sobre los distintos tipos de «pedagogías narrativas».

${ }^{2}$ Los ejemplos más nítidos son la novela de Alejandro Sawa, Criadero de curas (1888), en espacio de seminario, y la de José Zahonero, Barrabás (1890), en colegio «lazarista». En esta
} 
del subgénero se alcanza con los novelistas «intelectuales» de la Generación del 14, con producciones en las que, al hilo de la revisión de las experiencias autobiográficas de los escritores, se analizan desde supuestos pedagógicos las claves culturales del país. Un subgrupo importante es el formado por las novelas de contenido antijesuítico, cuyo punto de arranque, en esta etapa de esplendor, lo marca la novela de Gabriel Miró, Los amores de Antón Hernando (1909), con definitiva reformulación posterior en Niño y Grande (1922); tiene su epicentro en A.M.D.G. (1910) de Pérez de Ayala, al modo de Retrato de un artista adolescente de Joyce ${ }^{3}$, y se complementa con las llamadas novelas de Oleza (Nuestro Padre San Daniel, de 1921; y El obispo leproso, de 1926) del propio Miró4. De modo excepcional puede encontrarse alguna réplica narrativa a este tipo de literatura en la novela pro jesuítica, Los caballeros de Loyola (1929), de Rafael Pérez y Pérez.

El resto de las órdenes y congregaciones religiosas también tiene presencia en las novelas de las primeras décadas de siglo. En Las confesiones de un pequeño filósofo (1904), de Azorín, los padres profesores de las Escuelas Pías; en Pequeñas memorias de Tarín (1915) de Rafael Sánchez Mazas, los profesores de los Sagrados Corazones de Miranda de Ebro; en la novela de Azaña, El jardín de los frailes (1927), los Agustinos de El Escorial. En este último bloque de novelas, a diferencia de la novelística de internados jesuitas, se imputa a los religiosos-profesores más ignorancia que mala fe, por más que los autores ofrezcan un hilvanado de estampas colegiales en las que se satiriza a menudo la práctica docente.

De manera que el grueso de estas obras está impregnado del anticlericalismo proclamado y defendido por buena parte de los autores del momento. Tal actitud incide especialmente en la disección de los modos de actuar de la Orden de la «Ratio Studiorum», pero también de los responsables de la institución docente de los seminarios, como las dos muestras representativas que aquí analizamos, redactadas ambas en 19245, y debidas a Federico Carlos

misma época se produce cierta efervescencia de literatura antijesuítica, alguno de cuyos ejemplos presenta rasgos comunes a los de estos novelistas naturalistas radicales (por ejemplo, la novela Jesús, 1898, de Dionisio Pérez Gutiérrez, ambientada en internado docente al modo de la novela canónica francesa de Octave Mirbeau, Sébastien Roch, publicada en 1890).

3 R. J. Shorck, «Ayala's Joycean Portrait: AMDG», Comparative Literature Studies, 26, 1989, 50-70. Establece paralelismos y diferencias entre las dos novelas. La de Joyce se redacta entre 1904 y 1914, aunque fue publicada en 1916, y traducida al español por Dámaso Alonso en 1926.

${ }^{4}$ Podría añadirse el nombre de Luis Astrana Marín, autor en 1915 de una «novela», que es más bien un informe novelado, con el título La vida en los conventos y seminarios (Memorias de un colegial), con un yo autobiográfico testigo de lo que presencia. La novela de Joaquín Belda, Los nietos de San Ignacio (1919), recoge algunas de las marcas del género narrativo antijesuítico, servidas literariamente de forma sarcástica al amparo del género erótico en el que habitualmente se mueve ese autor.

${ }_{5}^{5}$ R. Senabre, Lengua y estilo de Ortega y Gasset, Acta Salmanticensia, Salamanca 1964, pág. 27. Este crítico ya ponía en conexión Mario en el foso de los leones con El jardín de los frailes, A.M.D.G., El obispo leproso y El convidado de papel. En el prólogo a la edición de esta 
Sainz de Robles y a Benjamín Jarnés, autores de Mario en el foso de los leones (1925) ${ }^{6}$ y El convidado de papel (1928), respectivamente.

El conjunto novelístico de Jarnés (1888-1949) se lee como ejemplo de prosa narrativa de los nuevos tiempos, en sintonía con la teoría formulada por Ortega en La deshumanización del arte. «Novela deshumanizada» impregnada de un humanismo nuevo que apresa la problemática del héroe contemporáneo, pero que hunde sus raíces en el viejo, al servirse de la tradición literaria clásica. El convidado de papel 7 tiene cabida dentro del magma de la novela lírica teorizada por D. Villanueva y R. Gullón ${ }^{8}$, que ven precisamente en el caso del escritor aragonés un proceso de adensamiento de los experimentos iniciados por Miró o Azorín. Jarnés explota el perspectivismo lírico para obtener un texto sujeto a una geometría fría, superadora del mero lirismo poemático de los antecesores, con incorporación, además, de elementos de técnica cinematográfica .

El héroe de esta novela de seminario, Julio Aznar, es «hermano» de los personajes principales autobiográficos de Miró, Pérez de Ayala o Azaña, entregados todos al paladeo de sensaciones y a la autorreflexión. Y como ellos remite, mediante el ejercicio introspectivo, al rescate de la vida humana, «objeto básico de la novelística de Jarnés» ${ }^{10}$. Es un náufrago y, como los otros «alter ego» de esos autores coetáneos, es observador e irresoluto pero con un talante activo en la búsqueda directa de la belleza.

Julio Aznar da coherencia narrativa a tres novelas, tomadas por la crítica como una trilogía que comprende El convidado de papel (1928), El profesor inútil (1926) y Lo rojo y lo azul (1932), en la medida en que en las tres se recrean etapas claves del autor ${ }^{11}$; como profesor particular y seminarista en

última obra, J. C. Mainer ha advertido también la relación de parentesco de esa misma serie literaria que integra un conjunto de «novelas gemelas»: B. Jarnés, El convidado de papel (prólogo de J. C. Mainer), Guara Editorial, Zaragoza, 1979, pág. 13. Cito en adelante por esta edición. G. García-Aguayo, «El jardín de los frailes versus A.M.D.G», Ínsula, XLV, 526, 1990, 16-17, pág. 16. Este último crítico vincula las novelas de Azaña y de Pérez de Ayala por lo que tienen de impugnación de falsificación pedagógica. Hay que señalar, en todo caso, la fuerte conexión que tienen todas estas narraciones con la novela de tesis anticlerical producida en el marco del Realismo español del XIX, y que ha sido bien estudiada en el clásico libro de B. J. Dendle, The Spanish Novel of Religious Thesis 1876-1936, Castalia y Princeton University, Madrid, 1968.

${ }^{6}$ Cito por F. C. Sainz de Robles, Mario en el foso de los leones (Novelería), Biblioteca Nueva, Madrid, 1925, con la signatura 2/ 85892 de la Biblioteca Nacional.

${ }^{7}$ El convidado de papel está compuesta, en su primera versión, por las mismas fechas de publicación de Mosén Pedro. Biografía (1924), aunque la aparición en libro lleve fecha de 1928.

${ }^{8}$ D. Villanueva, La novela lírica, Taurus, Madrid, 1983, 2 vols.; R. Gullón, La novela lírica, Cátedra, Madrid, 1984.

${ }_{9}$ R. Hershberger, «Filming the woman in Benjamín Jarnés's El convidado de papel», Letras Peninsulares ML, 7, 1994, págs. 193-208.

${ }^{10}$ E. Zuleta, «La novela de Benjamín Jarnés», Ínsula, 203, 1963, pág. 7.

${ }^{11}$ E. Zuleta, Arte y vida en la obra de Benjamín Jarnés, Gredos, Madrid, 1977, pág. 19. Esta autora había señalado la relación de El convidado de papel con otros textos, insertos en novelas, inequívocamente autobiográficos, tales como "Años de aprendizaje y de alegría», 
Zaragoza y como militar en esta ciudad y en Barcelona ${ }^{12}$. Con todo, El convidado de papel, junto con Lo rojo y lo azul, supone un extraordinario ejercicio de aclimatación del modelo narrativo alemán de Bildungsroman, enriquecido por el esquema de novela de aprendizaje francesa, uno de cuyos paradigmas es Rojo y negro de Stendhal, al que invocan inequívocamente estas novelas de Jarnés.

El convidado de papel remite, pues, a la experiencia personal real del estudiante Jarnés en el seminario de Zaragoza y a la del niño escolar en su pueblo natal, Codo, corroborando un aspecto en el que ha insistido la crítica, interpretando a Fernández Almagro, cual es que el novelista «tiene algo que contar», «tiene biografía» ${ }^{13}$. «Jarnés tiene cosas que contar: cómo recorría descalzo el camino de la escuela rural, cómo padecía clases de retórica y poética en el seminario zaragozano» ${ }^{14}$.

No se trata sólo de filtrar en los personajes rasgos de la propia vida, sino también de reabsorber las circunstancias biográficas para dotar a los personajes de ficción de máxima consistencia ${ }^{15}$. Es decir, Jarnés, maestro del género biográfico, escribe aquí la biografía del personaje Julio Aznar en el tramo de su etapa del seminario. La novela tiene así conexión con las marcas del género biográfico que prolifera en la época y que tiene en el escritor aragonés a uno de sus mejores cultivadores. Aunque los años del traspaso de siglos del estudiante y su entorno escolar sean vertidos literariamente de forma exquisita según el esquema de la novela lírica, hay cabida además para un hilo de discurso «regeneracionista», sobre el que últimamente vuelve la crítica, que da a esta obra de Jarnés una enjundia educativa equiparable a la de otros grandes escritores ${ }^{16}$.

Por su parte, Federico Carlos Sainz de Robles (1898-1983) es también autor de narrativas ${ }^{17}$ que tocan de lleno las preocupaciones pedagógicas y vocacionales

de filiación goethiana (en Viviana y Merlín, 1930) y «Viaje infantil», dentro de El libro de Esther (1935).

12 J. C. Mainer, Benjamín Jarnés, Caja de Ahorros de la Inmaculada de Aragón, Zaragoza, 2000, pág. 73; D. Conte, La voluntad de estilo. Una introducción a la lectura de Benjamín Jarnés, Biblioteca Nueva, Madrid, 2002, pág. 23.

${ }_{13}$ J. C. Mainer, Benjamín Jarnés, pág. 33. El adolescente Jarnés, el hijo número decimoséptimo de una familia rural, entra en el internado, como tantos otros, para evitar el «azadón».

${ }^{14}$ J. C. Mainer, «Creación y teoría literaria en Benjamín Jarnés», Jornadas jarnesianas, AA.VV., Institución Fernando el Católico, Zaragoza, 1989, 109-126, pág. 123.

${ }_{15}$ A. Pego Puigbó, «Las novelas de un biógrafo (Benjamín Jarnés)», Dicenda, 17, 1999, 157-176, pág. 168 .

${ }^{16}$ Una lectura de los años escolares de Jarnés en clave regeneracionista se encuentra en F. Lough, «El profesor inútil and the ethical aesthetics of Benjamín Jarnés», Bulletin of Hispanic Studies, 72, 1998, págs. 469-489.

${ }^{17}$ Aparte de la novela de Sainz de Robles aquí estudiada, hay que consignar un segundo título de este autor: La decadencia de lo azul celeste (Madrid, Biblioteca Nueva, 1928). El asunto de esta segunda novela lo presenta Nora del modo siguiente: «Noviazgo entre un apuesto profesor universitario y una gentil señorita; noviazgo contrariado, pero sólo en apariencia contrariado, según se descubre al final, de modo que la dificultad pueda excitar el romanticismo fantasioso de la sensible Maribel, cuyo acomodo urden en realidad los papás 
suscitadas en las novelas de internados religiosos de los escritores que dan a las prensas sus escritos en los años veinte. Interrumpió sus estudios en el Seminario Conciliar de Madrid para cursar posteriormente Derecho y Letras y convertirse en Archivero Subdirector de la Biblioteca y Museo Municipal de Madrid ${ }^{18}$. De modo que, siguiendo la estela de los novelistas intelectuales de la Generación del 14, quiere con su novela de internado hacer valer la condición de escritor al amparo de la primera parte de su propia experiencia autobiográfica ${ }^{19}$.

La novela Mario en el foso de los leones (1925) está construida por medio de adición de cuadros y estampas que, en sí mismas, alcanzan un alto grado de expresividad literaria, mayor incluso que en otras novelas gemelas de más calidad. Son los avatares del adolescente ingenuo y susceptible (Mario Aliaga) que, habiendo sido extraído de su ámbito familiar natural (un pazo gallego del norte de la provincia de Pontevedra), se ve sometido a la férula de los clérigos-profesores de un seminario de una vieja ciudad castellana (Urbérbiga de los Caballeros) que funciona, como reza el expresivo título, como foso de los leones en el que el educando puede ser devorado ${ }^{20}$. Sin embargo, a pesar de que el narrador se esfuerza en bucear en el mundo interior del personaje adolescente, este no acaba de cuajar como personaje redondo. El muchacho es «pavisoso, santirulico, dulzarrón, pintadito, callado, capirotón, hidalgo de fandanguillo, embrión de vate, santo de alfeñique o príncipe de cuento de Calleja» (páginas 107, 151, 351). Y es que tiene razón Eugenio de Nora cuando señala que a esta novela le falta «psicología en vivo» y algo de acción, en contraste con el exceso verbal del autor, puesto que el proceso interior del personaje principal se presenta como algo hecho, «no aprehendido en su anhelante dramatismo de cada instante, no sorprendido en su tensa verdad $»^{21}$.

y el novio, auxiliados — sin él saberlo, claro - por un burlado tercer hombre, en apariencia «candidato oficial», que es el que carga con las costas... si no es (podría sospechar el lector) el raptor y afortunado galán el que «carga» con una damita de «resultado» bastante dudoso y difícilmente soportable. Ver E. G. de Nora La novela española contemporánea, II, Gredos, Madrid, 1979 [1962], pág. 238. La tercera y última novela, inédita hasta 1963, Escorial: vida y transfiguración, insiste en el tema de la vocación mística en el marco simbólico del Escorial. El volumen titulado Madrid... y el resto del mundo, Editorial Cultura Clásica y Moderna, Madrid, 1959, contiene asimismo novelas breves y cuentos.

${ }^{18}$ E. Nora, loc. cit., pág. 235.

${ }^{19}$ Eugenio de Nora acertó a resaltar el perfil «intelectual» de algunos novelistas menores que han destacado más en otros campos profesionales. Entre ellos incluía a Ángel Valbuena Prat, Ricardo Gullón y al propio Federico Carlos Sainz de Robles. La labor de este último como intelectual polifacético queda plasmada en una amplia obra como historiador de la literatura, lexicógrafo, bibliógrafo, folclorista, crítico literario o dramaturgo: E. G. de Nora, loc. cit., pág. 218 y sigs.

20 Tal vez haya que volver la vista a la novela de W. Pater, Marius the Epicurean (1885). Manejo la edición de Jonathan Cape, Londres, 1933. Es Bildungsroman con impregnación también de la religión ambiente en el joven discente. Percibe la religiosidad romana con espíritu de artista y da cuenta del horror de los espectáculos de los anfiteatros. Su homónimo Mario Aliaga percibe asimismo el seminario como un foso de leones de aquella época.

${ }^{21}$ E. Nora, op. cit., págs. 236-237. 
El personaje principal, de menor edad que el seminarista jarnesiano, dispara igualmente el mecanismo de la introspección y escamotea cuanto le es posible la presencia de los moradores del espacio, ya decididamente hostil: «Le placía quedarse solo, como en esta tarde remansando dentro o la ciudad de Dios, ni observado ni compadecido de los demás, sino buscando y encontrando de sí mismo» (pág. 88) 22. En esta novela, al igual que ocurre con la de Jarnés, la fuerte presencia del discurso introspectivo del personaje principal no impide que el control de la narración esté puesto en manos de un narrador omnisciente (como también ocurre en A.M.D.G.), pues la literatura española de colegios muestra resistencia a otorgar totalmente la voz homodiegética al protagonista escolar, al hacer depender las riendas del relato de una tercera persona que lima las notas redactadas previamente por el adolescente.

\section{Espacio y tiempo como marcas del género}

En las novelas de internado, el profesor no suele ser un «personaje redondo» y queda configurado como tipo que suma sus características a las del resto del claustro, conformando casi siempre un personaje colectivo oponente que impide el buen desarrollo del escolar. Ello resulta evidente en estas dos novelas cuyo espacio docente es el seminario (también en las novelas con internado jesuita). Las marcas formales espaciales resultan especialmente significativas, pues el establecimiento docente es percibido como un lugar hostil en el que el muchacho se siente prisionero. En las dos novelas este elemento narrativo se funde con el personaje profesoral colectivo, constituyendo un bloque que trabaja para la «antiformación» del escolar niño o adolescente.

En El convidado de papel el espacio asume con claridad esa función sintetizadora de todos los personajes oponentes. El héroe se sirve de variados expedientes, filtradores de la vida, para conjurar lo que significa el muro docente como elemento represor de la vida. De ahí la necesidad de construcción introspectiva de un nuevo espacio interior del protagonista para conjurar la represión que impone la disciplina del seminario, simbolizada en el interior de los muros. Dentro de los recursos puestos al servicio de exorcizar las represiones se sitúa el río Ebro, excepcional reflector, al que Julio entrega cartas y confidencias, y que simboliza la fuerza de la vida, a la que nunca renuncia el héroe. Por eso el espacio fluvial sirve para enmarcar el comienzo y el final. Aunque la construcción espacial sea una operación más de la potencia intelectual del personaje

${ }^{22}$ Como en la novela de Azaña, los compañeros de estudios, presentes normalmente en estas novelas con funciones auxiliares para aliviar las penas del héroe, son reducidos a un conjunto borroso, sin vinculación afectiva con el narrador. De modo análogo se expresa el narrador innominado de El jardín de los frailes: «El áspero compañerismo abonaba mi propensión a sublimar las cosas: un árbol, el mejor camarada, y más amables; la mejor sociedad, el bosque» (pág. 150). Los compañeros suponen, pues, paradójicamente, un acicate para el regodeo intimista y para hacer avanzar los aprendizajes hacia los dominios del artista. 
principal, la Zaragoza (Augusta en la ficción) del cambio de siglo aparece evocada con nitidez, tal como ha explicado con detalle Ildefonso Manuel Gil23: la plaza de La Seo, el Arrabal, la arboleda del Ebro, microespacios contrapuestos siempre al del interior de los establecimientos docentes.

La menor edad del escolar de la novela de Sainz de Robles propicia que el elemento espacial de Urbérbiga de los Caballeros sea más constrictivo aún que lo que supone Augusta para Julio Aznar. Como espacio preambular, inserto en el capítulo primero de presentación de los antecedentes, está el lugar natural infantil de La Gándara con el pazo y el deambular libre del niño bajo la tutela del buen preceptor, don Miguel de los Santos (con la prolongación, rememorada, del espacio de la ciudad de Madrid en la que ha pasado alguna temporada la familia hidalga). Se trata de un perfecto correlato, por otro lado, de un episodio análogo en la novela de Jarnés: la inserción en forma de obertura del personaje de la maestra rural Eulalia que simboliza la exaltación de la edad feliz de la niñez y la acción educativa libre de prejuicios.

El inicio del segundo capítulo marca la introducción definitiva del escolar en el recinto religioso, una vez operado el primer paso de la salida del lugar de origen exigido por el género de la novela de formación. El autor sumerge al catecúmeno en un espacio descrito definitivamente como cárcel ${ }^{24}$, empujado por toda suerte de mediaciones negativas, del que tendrá que huir como único recurso posible de salvación. Como en Criadero de curas de Alejandro Sawa, en esta novela de Sainz de Robles, el espacio escolar se incrusta en otro mayor, conformado por la ciudad levítica castellana con nombre particularmente expresivo: un receptáculo pétreo en consonancia con el establecimiento docente.

La caracterización de este espacio novelesco apunta a las notas de oscuridad, frialdad y tenebrismo; y toda la actividad académica lleva adherida una focalización espacial del mismo tenor: ejercicios espirituales en ambiente tenebroso, habitaciones tétricas donde agonizan escolares tuberculosos, celdas con clérigos untuosos. Incluso la composición espacial negra sirve de receptáculo para otras actividades docentes como clases de literatura o lectura de notas.

El único microespacio que se sale de este patrón es el jardín (a la manera de la novela de Azaña), que aporta al adolescente algún nutriente necesario para la resistencia, pues contribuye a la introspección y a la configuración de

${ }^{23}$ I. M. Gil, Ciudades y paisajes aragoneses en la obra de Benjamín Jarnés, Zaragoza, Institución Fernando el Católico, Zaragoza, 1988.

${ }^{24}$ En las novelas naturalistas de internados se describe el espacio docente como cárcel, en el que siguen insistiendo los novelistas de las primeras décadas del siglo Xx. En el caso de Criadero de curas, la ciudad de Ávila es utilizada literariamente como símbolo de aislamiento y, en seguida, la institución docente aparece asimilada a cárcel, cloaca o infierno. Ver F. Gutiérrez Carbajo, en «Introducción» a A. Sawa, Criadero de curas, Biblioteca de Autores Españoles, Madrid, 1999, pág. 61. En Barrabás, de José Zahonero, el establecimiento docente es una cárcel o una gran jaula dentro de la cual se encuentran espacios más reducidos (aulas, salas de castigos), presentados por el narrador como lugares de tortura. 
su personalidad de artista25. Pero el verdadero espacio, al igual que en El convidado de papel, es el espacio verbal que construye Mario Aliaga como parapeto de los hostigamientos. Y quizás el símbolo verbal de la construcción intelectual del muchacho sea la imagen recurrente de la Ciudad de Dios, emblema del desiderátum religioso del escolar que contrasta con la sociedad del seminario. La comunidad educativa (como ocurría en novelas como Criadero de curas y en A.M.D.G.) es justamente la antítesis de la Ciudad de Dios; y por ello la huida se convierte pronto en el único asidero posible. El adolescente no tiene cabida en tal recinto, del mismo modo que Dios, que aparece sistemáticamente aherrojado de un lugar destinado a la formación de clérigos. Por eso, hasta que llega el momento de la salida, la novela genera la construcción de ese espacio interior propio del adolescente, poblado de imaginería cristiana y de historia bíblica, que se funde con otro tipo de sueños y pensamientos: un espacio en definitiva que tiene su impronta en el discurso de conciencia del protagonista.

El elemento narrativo del tiempo, estrechamente relacionado al espacio, se suele acomodar en estas novelas colegiales al curso académico, tomado como unidad significativa y, aunque el tramo educativo conste de varios cursos escolares, el novelista suele focalizar la actividad docente de uno solo (trunco, en el caso de la novelística naturalista), al considerarlo suficientemente representativo para apuntar el elemento de anti-formación. Tal disposición temporal permite además dar cabida a la recreación literaria de los hitos comunes del calendario escolar.

En El convidado de papel el tratamiento del tiempo se somete a ese patrón del año académico habitual (aparte el prólogo de los momentos de escuela infantil), pero este tiempo cronológico queda de nuevo subsumido en un tiempo psicológico que ha forjado el diseño intelectual del personaje, quien muestra autocomplacencia en la recreación de su realidad y, por ejemplo, inventa contextos que permiten explicar determinadas situaciones (evocación del pasado pecaminoso del cura-fauno Bruno). Se trata de un tiempo psicológico que, en ocasiones, se funde con el tiempo mítico ucrónico habitual en la obra del escritor (Eulalia es Dánae); pero, en todo caso, no oculta una referencia inequívoca a los años del cambio de siglo, como momento del tiempo histórico real, en coincidencia con la novela El jardín de los frailes de Azaña, con la que El convidado de papel conecta además en lo que se refiere a la densidad conceptual del discurso narrativo ${ }^{26}$.

${ }^{25}$ Mario Aliaga no llega a tanto como el narrador innominado de El jardín de los frailes, quien logra sublimar el espacio opresivo hasta convertirlo en un locus amoenus al que el Azaña adulto regresa una y otra vez, tal como testimonian sus Diarios. Ver M. Azaña, Diarios completos. Monarquía, República, Guerra Civil (ed. de Santos Juliá), Crítica, Barcelona, 2000, pág. 186.

${ }^{26}$ El jardín de los frailes aparece inicialmente publicada de forma fragmentaria en la revista creada por el propio autor, La Pluma, durante los años 1921 y 1922, aunque Azaña la haya iniciado mucho antes, para quedar definitivamente como libro unitario en 1927. 
En Mario en el foso de los leones el narrador presenta en el primer capítulo los antecedentes familiares del héroe sirviéndose de técnicas que agilizan la coordenada temporal: así, el resumen y la elipsis. A partir del inicio del segundo capítulo se desgrana con lentitud toda la historia de iniciación que comprende asimismo los nueve meses del curso escolar. Es ese un lapso suficiente para que aflore el perfil de «niño sensible y poeta» que escribe su propio diario y que se educa como literato, realizando un esfuerzo gigantesco para la evitación de la salida anticipada del recinto.

El curso académico funciona como marco temporal que proporciona además unos hitos colegiales, evocados en esta novela con mayor detalle que en la de Jarnés: el primer día de curso, los tres meses de vacaciones, primera comida comunitaria, los ejercicios espirituales, o el final de curso con el reparto de premios y calificaciones. Elementos estos que posibilitan el hilvanado de la anecdótica colegial en una novela que es especialmente rica en documentación, con algún parecido por aquí con A.M.D.G.

Los sueños del personaje escolar funcionan como prospecciones que anticipan el desenlace, del mismo modo que el final de la novela de Jarnés, en forma de huida del seminario, y en salida nocturna acompañado de su antiguo preceptor. Asimismo, la consideración del mundo familiar dejado atrás gana intensidad conforme avanza el discurso novelístico, merced ahora al uso narrativo de la retrospección. En definitiva, en las dos novelas, el tiempo, lo mismo que el espacio, se torna psicológico y se construye en la conciencia del personaje.

El componente autobiográfico de la novela de Sainz de Robles se pone de manifiesto, como ocurre siempre, a través de las marcas temporales que señalan el tiempo de la historia, correspondiente al de la etapa del autor como seminarista. Quizás a efecto de la datación novelesca, la información más explícita se inserta en el programa del certamen literario que se celebra hacia final de curso (pág. 300). Se presenta en un llamativo diseño editorial con autentificación de la fecha de los años diez del siglo XX, con ausencia de la cifra de las unidades. El dato es suficiente para remitir el tiempo de la historia a los años adolescentes del autor. Con todo, como sucede en la novela de Jarnés, están ausentes las referencias a hechos históricos que pudieran contextualizar con mayor precisión los momentos narrados, a diferencia, por ejemplo, de lo que sucede en A.M.D.G. ${ }^{27}$.

${ }^{27}$ Mucho más connotado está el tiempo narrado en las otras novelas gemelas. En El jardín de los frailes la fecha de 1898 coincide con el examen de licenciatura del protagonista, una vez fuera del Escorial. A.M.D.G., que está fechada el año del fusilamiento de Ferrer Guardia, se refiere al curso de 1894, en el colegio de Gijón, donde estudia el autor. Ver M. D. Albiac, «La Semana Trágica de Barcelona en la obra de Pérez de Ayala», Ínsula. XXXV, 404-405, 1980, 3-4, pág. 3; y A. Amorós, «Introducción» a R. Pérez de Ayala, A.M.D.G., Cátedra, Madrid, 1995, pág. 64 . 


\section{Costumbres escolares y tipos}

La novela de Jarnés, caracterizada por la densidad del monólogo lírico, también da cabida, es verdad que de forma esquemática, a la descripción de la tipología humana consustancial en el subgénero. Y así aparecen los colegiales que se intercambian lecturas de todo tipo. De entre ellos, el narrador destaca uno que se convierte pronto en confidente de Julio. Es Adolfo, colegial nuevo que se incorpora al seminario con el recuerdo aún vivo del verano. Se evoca la vuelta de vacaciones al recinto escolar con un Julio adolescente en la ciudad de Augusta, lleno de resaca estival tras su experiencia sexual con Araceli28. Son los recuerdos previos a la reintegración en el establecimiento docente, visto como siempre, como espacio de reclusión («como una gran colmena eclesiástica», pág. 49). «Faltaban unas horas para ser engullido por el ceñudo laboratorio sacerdotal, por ese fosco reglamento que prohíbe toda excursión no realizada en masa y en fila de a tres» (pág. 37).

La pareja de amigos, cuyos nombres invocan a los héroes literarios de las obras de Stendhal (Rojo y negro) y de Benjamín Constant (Adolfo) ${ }^{29}$, adquiere de entrada una evidente potencialidad metaliteraria sobre la que el autor hace canalizar el discurso. Fuera de Adolfo, el autor pasa por encima la observación pintoresca de otros tipos estudiantes y sólo muy tenuemente quedan apuntados, ya en el último capítulo, escolares como Manolo, que encaja bajo la tipología de glotón, o Tovar, prototipo del alumno díscolo.

La vida colegial empieza a rodar y cada seminarista recibe la asignación de su celda y las primeras instrucciones de comienzo de curso. El mozo se da de bruces con la actividad escolar con los textos latinos, los fámulos y los profesores que van y vienen. Ahí aparece don Mariano, «un jayán de la sotana torturada» (pág. 44), caracterizado por medio de los procedimientos tipificadores habituales: «Por un perenne milagro de resistencia, aquella torturada sotana sigue venciendo las violentas embestidas del vientre. Es don Mariano, un sacerdote de la casa, amigo de secretear con los adolescentes de quienes conoce su pequeña y uniforme vida interior. Goza del humorismo jovial de todo hombre resignado a ser obeso» (pág. 41).

Como en las otra novelas gemelas, en El convidado de papel se evoca la primera noche en el refectorio, con sus características lecturas en voz alta a cargo de los colegiales, aunque se cede enseguida paso al paladeo íntimo del escolar protagonista que repasa las pertenencias queridas de su baúl. Es decir, la novela no puede sustraerse por completo a la porción de realismo y de costumbrismo escolares inherente en el subgénero; y por eso se describe al profesor de Historia

\footnotetext{
28 Recuérdese que el narrador innominado de El jardín de los frailes alude a una experiencia sexual parecida en la misma ciudad de Zaragoza, en una fecha próxima a la que se narra en esta novela de Jarnés. Y en todo caso, el motivo de la desfloración sexual del adolescente en verano y bajo estipendio constituye casi un lugar común en estas novelas.

${ }^{29}$ Adolfo (1816) es obra maestra de la literatura francesa, con plasmación de la pasión y exaltación de lo femenino.
} 
actuando en su clase al modo de los retratos humorísticos de novelas como A.M.D.G. y otras afines:

Minutos después entran los colegiales en el aula. La clase de historia tiene lugar en una enorme sala de pupitres a la que - siempre rumiando alguna frase memorable - sube solemnemente el doctor Ropón, sesudo profesor de historia, completamente alejado del momento actual por espíritu de disciplina. No hurta a sus funciones profesorales ni un átomo de obediente mentalidad, hasta el punto de haber logrado acomodar a la sensibilidad de cada época en estudio, su propia sensibilidad. Durante los siglos de las cruzadas se derrite en hilos de fuego retórico, que recuerdan a Pedro el Ermitaño. Durante la época arriana le consume el fuego de Nicea, y durante la época de Lutero, la llama aséptica de la Santa Inquisición. Unos días se ve en él a San Cipriano, otros a Savonarola, otros a Augusto Nicolás (pág. 117).

Más adelante:

El doctor Ropón se llama como un profesor cualquiera, pero su fina urbanidad le llevó a caer bajo la sátira implacable del astuto labriego Pla. Cierto día dejó el profesor olvidado su manteo, y acercándose a Pla, le dijo cortésmente: «¿Quiere usted ir a buscar mi ropón?». No necesitó más pergaminos el alumno. Nemine discrepante, a aquel hombre delicado que olvidaba sus prendas de abrigo, le fue expedido el título académico y sastreril de Doctor Ropón. El cual goza siempre de tan selecta producción retórica, que, despliega la misma gentileza con que un caballero versallesco hubiese invitado a bailar a una dama. Suele decir: «señor Martínez... Hoy quedará usted sin solaz» O también: «No disfrutará usted esta semana de esparcimiento alguno» (pág. 124).

Por su parte, los personajes de la sociedad del seminario castellano de la novela de Sainz de Robles, perfectamente integrados en el espacio cerrado, ponen al héroe adolescente al borde de la consunción. Incluso los propios compañeros seminaristas, algunos de ellos con funciones de fámulos, se integran en el bando opositor del mismo modo que la mayor parte de los clérigos. Pero son estos últimos quienes forman en su conjunto un bloque sin fisuras, caracterizados según el modo realista-expresionista. Los profesores titulares aparecen dibujados, de igual modo, con suficiencia expresiva por el camino del humor galdosiano. Ahí está, a título de ejemplo, el beocio Don Manuel Pérez de la Ossa, segundo prefecto de disciplina, descrito como otro Dómine Cabra: «con su nuez descomunal, en la que habían crecido cuatro pelos, sujetos ahora con un lazo rosa» (pág. 70) ${ }^{30}$.

${ }^{30}$ En Mirando a Loyola (1913), ajuste de cuentas de Julio Cejador con la orden jesuita, hay ocasión también para la descripción de tipos clérigos con la misma expresividad que los de Mario en el foso de los leones o A.M.D.G. Véase cómo describe emulando, aquí también, el retrato quevedesco del Dómine Cabra, al ángel guardián que asignan al recién incorporado 
Si Jarnés presentaba al profesor de Historia en acción, Sainz de Robles hace lo mismo con el de Retórica en el capítulo sexto, «Los devoradores de inmortalidad». Se trata del profesor don Ángel de la Guarda Ríu y Felíu, que prepara con sus alumnos un certamen en honor al «obispo de Ávila», el Tostado. Se verifica ahora de qué naturaleza es el contenido literario recibido por el escolar: falsificación modernista. El profesor es a la vez poeta de composiciones tituladas «Espinas y flores», «Suspiros y ayes», «Vergel con espinas», «Flores místicas», «Rosas sin espinas», que inserta ocasionalmente en hojas parroquiales. Sus clases son alegatos contra la poética novecentista y loas de un modernismo, caracterizado por la sonoridad, la vena y el sabor rítmico, y todo ello servido en forma dramatizada y libre por un narrador omnisciente que satiriza la pedantería y mal gusto profesoral.

Este maestro, que practica en el aula el método socrático, dialoga de poética con sus alumnos. Al «señor Antúnez, don Rufo» le fustiga el soneto leído «por ausencia de inspiración y falta de modestia», a la vez que se van desgranando los versos con divertimento y jolgorio del resto de estudiantes. Lanza ahora el envite a su alumno preferido, Luis Rivadeneira, «continuador de su estro florido» $\mathrm{y}$, posteriormente y a través de la delación del alumno Gil Herrán, sale a la luz la condición de poeta secreto de Mario Aliaga, que es invitado a leer una pesada composición de cincuenta y siete alejandrinos, transcritos uno tras otro por el narrador ${ }^{31}$. Tras la lectura, el profesor descubre en Mario al verdadero discípulo. Es el preámbulo que cede paso a la celebración del certamen literario, con discurso plúmbeo de don Ángel de la Guarda, recreado por el autor como ejemplo de falta de estética. Barcarolas ridículas, poemas deleznables y reparto de premios, con exhibición de la arbitrariedad académica del jurado y regalos, en su mayor parte de «utensilios metálicos averiados». Esta galería de tipos queda recreada con exceso de adobo literario, pero con la intencionalidad de subrayar la mezquindad y ruindad moral e intelectual de unos personajes que empujan al estudiante protagonista a la huida.

La riqueza expresiva va acompañada del repaso de la anécdota colegial, en forma de enumeración de bártulos escolares y vestuario; el inevitable paseo de los jueves, la explicación pintoresca de métodos de castigo como el «tobazo» (el resultado de salir el dedo corazón disparado desde la catapulta del dedo pulgar, pág. 104), los mamporros «de sobaquillo» o «de cuello vuelto», todo ello aderezado con la jerga estudiantil que recoge términos como «soplones»,

al noviciado: «Llevaba una sotana tan sebosa como los demás que hasta allí había visto, y por lo alto de ella se escapaba un cuello, que presto se doblaba hacia delante, cigüeñil y poco airosamente, como de jirafa, y sobre él una cabeza estrecha de sienes; rapada de cogote, orejas como dos buenas asas, ojos cerradizos, que jamás supe de qué color fuesen, según los tenía de bajos y entornados; quijadas esquinudas, mejillas hundidas y amarillas, labios apretados [...]. Calzaba unos zapatones de munición, que a duras penas meneaba sin chacolatear, tranqueando, cual si anduviera entre cáscaras de huevos procurando no pisarlos ni meter ruido» (pág. 95).

${ }_{31}$ En A.M.D.G. se satirizan con saña las declamaciones poéticas o las actividades literarias afines. 
«fuelles», «chivatos», «se sollipaban», «somanta», «achantarse», «pirrarse», «zurríos». O la lectura solemne de los nombres y las calificaciones finales el día 21 de junio (pág. 346), que, a diferencia de los institutos y universidades, se cantan en público y en latín («Meritissimus», «benemeritus», «meritus», pág. 348).

\section{Novela de artista: educación literaria}

La propensión hacia el aprendizaje del artista-literato posibilita que el personaje adolescente de este grupo de novelas de internado se convierta en narrador de su propia etapa formativa, aunque sea desde la omnisciencia editorial. De ahí la insistencia en insertar dentro de las historias elementos metaliterarios, o en formalizar estructuras narrativas cercanas a la «novela de artista» o Künstlerroman ${ }^{32}$. Y es que esta modalidad es una variedad del esquema Bildungsroman, especialmente productiva en las novelas europeas modernistas (también en las españolas) de sátira de internados religiosos ${ }^{33}$, pero con floración inicial en la novelística alemana del Romanticismo (Heinrich von Ofterdingen de Novalis o Hyperion de Hölderlin) $)^{34}$.

${ }^{32}$ El Künstlerroman es un subgrupo de novela que focaliza la formación del protagonista a través de su carrera artística con preferencia, en los modelos canónicos alemanes, por la pintura o la literatura. Una bibliografía sumaria sobre la «novela de artista», construida a partir de la teorización de H. Marcuse (ver traducción al italiano, Il romanzo dell'artista nella letteratura tudesca, Einaudi, Turín, 1985) contiene referencias como: M. Beebe, Irony Towers and Sacred Founts: the Artist as Hero in Fiction from Goethe to Joyce, UP, Nueva York, 1964; A. W. Phillips, «El arte y el artista en algunas novelas modernistas», en Temas del modernismo hispánico y otros ensayos, Gredos, Madrid, 1983 [1974], págs. 261-293; R. Gutiérrez Girardot, Modernismo, Montesinos, Barcelona, 1983; E. Neumann, Mitos de Artista (Estudio psicohistórico sobre la creatividad), Metrópolis, Madrid, 1986; F. Calvo Serraller, La novela del artista: imágenes de ficción y realidad social en la formación de identidad artística contemporánea (1830-1850), Mondadori, Madrid, 1990; R. Seret, Voyage into Creativity: the Modern Künstlerroman, Peter Lang, Nueva York, 1992; Nil Santiáñez-Tió, «El héroe decadente en la novela española moderna (1842-1912)», Boletín de la Biblioteca Menéndez Pelayo, 71, 1995, páginas 179-216; Y. Latorre, Musas trágicas (Pardo Bazán y las artes, Pagès, Lérida, 2002; y F. Tomás (ed.), En el país del arte. Tercer encuentro internacional. La novela de artista, Biblioteca Valenciana, Valencia, 2003; o F. Plata, La novela del artista, Fondo de Cultura Económica de España, Madrid, 2014.

33 Junto a A Portrait of the Artist as a Young Man de Joyce (1916) hay que considerar la efervescencia de una literatura europea, a primeros de siglo, que insiste en esta temática. Ver para el Bildungsroman europeo de principios del Xx el libro de F. Moretti, Il romanzo di formazione, Einaudi, Turín, 1999. Incluye un último capítulo nuevo («Un’inutile nostalgia di me mesmo. La crisi del romanzo di formazione europeo, 1898-1914», págs. 57-273) en el que se estudia, precisamente, ese ramillete de novelas anti-Bildungsromane, formado por Tonio Kröger de Mann (1903); Törless (1906) de Musil; Jakob von Gunten de Robert Walser (1909) y la propia novela señalada de Joyce. Todas estas narrativas glosan el refugio del protagonista en su propio yo como medio de exorcizar el peso de la irracionalidad de la escuela, casi siempre en la modalidad de internado religioso.

${ }^{34}$ Los géneros fronterizos del Bildungsroman aparecen estudiados en su decurso histórico por M. Á. Rodríguez Fontela en su libro: La novela de autoformación. Una aproximación 
El Jarnés crítico literario propicia de modo natural que la metaliteratura se convierta en uno de los ejes estructurantes de El convidado de papel, también de sus otras novelas, haciendo posible el aprendizaje estético del héroe ${ }^{35}$. Y, claro está, no están nunca ausentes los grandes clásicos europeos del aprendizaje en el taller del escritor ${ }^{36}$. Ello tiene su plasmación más expresiva en los sucesivos «banquetes de papel» que jalonan el discurso interior del personaje y que se suceden desde el inicio de la novela (el primer capítulo se presenta esquematizado en seis epígrafes que revelan el tenor del contenido: «Escenas junto al pretil»; «La voz de Dios»; «El amor solloza»; «El aduanero de equipajes líricos»; «Primer banquete de papel»; «Profanación de una noche de otoño»).

La vocación artística del protagonista se traduce en el «film»y «la composición de lugar» que permiten hacer volar la fantasía por encima de la menudencia colegial cotidiana. Por la «pantalla» desfilan mujeres como Lucía o Nieves; y los paseos extramuros de Augusta se aprovechan para el paladeo hiperestésico, la vista con delectación de la mujer o la contemplación del mercado. En los momentos de enclaustramiento también se activa el dispositivo de la fantasía, pues una lectura tediosa en voz alta, una misa de Mosén Bruno (el pecador castigado) o cualquier otro momento de la actividad colegial pueden ser ocasión para que Julio Aznar haga más vigoroso el mundo de su fantasía y afile el instrumento lingüístico para convertirse en $\operatorname{artista}^{37}$.

Significativa es la evocación del «segundo banquete de papel» (capítulo segundo), en medio del estudio vigilado por el inspector Monsieur. Las lecturas heterogéneas y extraacadémicas funcionan narrativamente como elemento auxiliar que ayuda a sacudirse el yugo de la disciplina ideológica del seminario. Boccaccio, Quevedo, Manzoni, Coloma, Fernán Caballero, Pereda, Padre Aretino, Chateaubriand, Zorrilla, Arolas, Goethe, Valera o Galdós. Todo ello entremezclado con estampas, cartas y fotografías que se intercambian los estudiantes ante el inspector, que sólo es capaz de moderar su saña cuando Julio urde la mentira exculpatoria de que las risas indisciplinadas, en un momento del estudio,

teórica e histórica al Bildungsroman desde la narrativa española, Kassel, Universidad de Oviedo, 1996. Pueden verse de modo más sintético en el libro de J. S. Fernández Vázquez, La novela de formación. Una aproximación a la ideología colonial europea desde la óptica del Bildungsroman clásico, Universidad de Alcalá, Madrid, 2002. Ver especialmente «Las fronteras del Bildungsroman», págs. 74-80.

${ }_{35}$ Desde siempre la crítica ha insistido en la conexión del ideal educativo jarnesiano con Schiller, en tanto que se concede importancia a la educación estética del hombre. Ver E. Zuleta, Arte y vida; V. Fuentes Benjamín Jarnés: Biografía y metaficción, Institución Fernando el Católico, Zaragoza, 1989.

36 Un repaso al repertorio de obra crítica de B. Jarnés reunido y editado por D. Ródenas de Moya, Obra crítica, Institución Fernando el Católico, Zaragoza, 2001, nos lleva a reseñas y reflexiones sobre autores como Rousseau, Goethe, Stendhal.

${ }^{37}$ Se trata de un recurso puesto al servicio del tema, «el instrumento de la consolación y compensación psicológica, instintiva, de Julio y, a su vez, el proyector que refleja la íntima entidad de sus insuficiencias» (J. Gracia, La pasión fría. Lirismo e ironía en la novela de Benjamín Jarnés, Institución Fernando el Católico, Zaragoza, 1988, pág. 79). 
son imputables a los argumentos disparatados de los filósofos krausistas: «Importa leer, sea lo que sea, porque cada día son más hondas las desavenencias entre los colegiales y el texto» (pág. 94).

«En nuestros banquetes ideales hay siempre invitada una mujer» (pág. 84). Son los convidados de papel que dan título a la novela. El texto de la vida se cuela por las rendijas del salón de estudio y los personajes sensitivos procesan los tangos lúbricos que suenan en el exterior urbano, o la cópula rítmica y simétrica de los matrimonios del inmueble contiguo al seminario. La clase de literatura, en fin, es buena ocasión para la composición literaria de bagatelas poéticas lanzadas al río Ebro, contemplado desde las ventanas del aula por los colegiales $^{38}$. Julio da forma a un conjunto de letanías que hacen al padre Ebro el mejor de los confidentes del joven poeta en ciernes. Es la letanía sobre el pretil cuyo comienzo, desgranado en breves apóstrofes, se inserta dentro del texto novelesco:

Ebro, mi fiel amigo, por tus lecciones de perenne inquietud, recibe mi saludo de apasionado y obediente discípulo. Pretil, barbacana sobre lo huidizo: no pretendas robar su contenido eterno al agua que - inflexible- arrastra las moléculas del tiempo (pág. 121) ${ }^{39}$.

A partir de aquí el narrador ha dispuesto el oportuno contexto para la inserción del «tercer banquete de papel», en el que se siguen repasando libros y autores varios, que complementan el bagaje del seminarista para activar las capacidades para la escritura (Pepita Jiménez, Manón, La Hermana San Sulpicio, Pablo y Virginia). Hay además otra literatura de consumo obligado por los seminaristas que deben escuchar en voz alta en el refectorio, compuesta por hagiografías, novelitas blancas, o en la línea del padre Coloma. Y, en algunos casos, literatura religiosa sobre las «Postrimerías», al modo de la retórica de los ejercicios espirituales.

El cuarto y último capítulo aún contiene otro banquete de papel («Cardenio, el aturdido», «La revisión de intimidades», «Último banquete de papel», «El amor ebrio» y «Epílogo sobre el pretil»). La tesis hedonista lanzada en el prólogo es confirmada mediante Eulalia (antigua maestra rural de Julio), amante ahora del amigo Adolfo. Julio queda confirmado ante Eulalia como escritor puesto que ella desea que sea él quien ponga en limpio la novela de los dos amantes (Eulalia y Adolfo): «Te llamamos nuestro poeta. Confiamos en que algún día has de escribir nuestra novela, por eso te queremos tanto. Sin ti no seríamos nada» (pág. 158). La información necesaria está contenida en un sobre suministrado por Eulalia. Zuleta constata que el episodio de la entrega a Julio de la carta del borrador de la biografía de Eulalia es un añadido nuevo de la segunda versión especialmente significativo dentro de la estructura del texto definitivo,

\footnotetext{
${ }^{38}$ De la sede principal del Seminario de San Carlos mudan pronto los colegiales al edificio auxiliar situado junto a la Lonja de Zaragoza.

${ }^{39} \mathrm{El}$ autor ensaya aquí sus Cartas al Ebro (Biografía y crítica), publicada en 1940.
} 
pues refuerza más aún el componente metaliterario y redondea el perfil del personaje como «artista adolescente $»^{40}$. Julio Aznar relee a escondidas ese borrador, del que el narrador omnisciente da cuenta fragmentaria, pero el texto queda cortado bruscamente y Julio reorienta su actividad. Quiere sensaciones nuevas. Se siente mal con Adolfo y sale a la ciudad para recibir nuevos estímulos del río: «Quiere leer precipitadamente la última página del libro para abrir su atención a otra ventana. La de Adolfo comienza a producirle hastío» (pág. 169).

Por su parte, el niño escolar del seminario de Urbérbiga de los Caballeros desarrolla igualmente la faceta artística; unas veces se sumerge en su pensamiento, otras juega ensimismado con álbumes de estampas «de negro y colorines», tal como reza el título del capítulo tercero, que presenta además información complementaria sobre organigramas escolares, juegos y maneras pedagógicas de los profesores. Mario sigue desarrollando su faceta literaria y artística, ora contemplando líricamente desde su ventana, al modo noventayochista, el campo castellano ( $¡ A y$, qué gracia lírica la de contemplar a Castilla del romancero a primera noche de noche clara», pág. 157) ${ }^{41}$, ora recitando para sus adentros poemas con ribetes místicos. Tal exacerbación desemboca pronto en el desvanecimiento y en la fiebre alta.

Paradójicamente, resulta significativo el quinto capítulo, presentado como una «digresión prescindible» que viene a reproducir directamente el cuaderno de notas del seminarista en primera persona, corroborando la condición real de poeta o literato del muchacho. Aun así, al modo de las Pequeñas memorias de Tarín, tales apuntes quedan retocados ligeramente por el narrador ${ }^{42}$. Mario atestigua, en reflexiones organizadas en torno a «capitulillos» breves, su condición de poeta hiperestésico que siente la necesidad de incluir versos con aliento místico popular, entremezclados de una pretendida prosa poética modernista. Todo son «sueños», «ilusiones» y «sensaciones» («Yo soy un poco poeta y la poesía ha de espolvorear mis horas», pág. 231). Se suceden las imágenes de colores, piedras preciosas, emociones y notas que se funden en sinestesias continuadas.

${ }^{40}$ E. Zuleta, Arte y vida, pág. 144.

${ }^{41}$ Es habitual la invocación al paisaje castellano como nutriente estético del estudiante artista. Algo de eso hay en Las confesiones de un pequeño filósofo o en El jardín de los frailes. El escolar Tarín de la novela de Sánchez Mazas Pequeña memoria de Tarín apostrofa igualmente desde el internado religioso de los Sagrados Corazones al paisaje castellano, cuando pasea por la carretera de Burgos, con versos copiados del escolar literato de sexto curso, Guillén: «Solar de Castilla, la noble, la hidalga/por donde una vieja leyenda cabalga/de Rodrigo Vivar en la silla/ ¡Solar de Castilla!» (pág. 71).

${ }^{42}$ En nota a pie de página de la novela se dice: «Este capítulo, o el capítulo este, realmente, sobra; realmente no es capítulo. ¿Por qué, pues, está entre capítulos numerados, correlativo con ellos? Es una digresión y no un nexo, conforme. Es un inciso [...]. Quien sea poco amigo de cogitaciones transcendentales o nimias, que poco importa la distinción, sáltese este capítulo que no lo es y que no va adentrado en la fábula [...]. Pero en el cuaderno íntimo de Mario Aliaga — del que yo selecciono estas notas, cuyo léxico pulo — ¡tantos matices selectos hay!... que para mejor entendimiento del espíritu del héroe, creo necesario transcribirlos y darlos a conocer. La poesía es un perfume. Mario Aliaga es un poeta (Nota del transcriptor) (pág. 221). 
El autor se mueve, a lo largo de todo el curso narrativo, por el terreno de la novela dramatizada, tal como se ilustra gráficamente en el episodio de la reproducción teatral a varias voces, en el que el jardín funciona como escenario de una comedia y donde el discurso «tardomodernista» camina hacia la búsqueda mística. El muchacho prefiere la noche como momento de introspección, apto para la conformación de una personalidad definida por los sentimientos de emoción y de piedad. Se suceden expresiones tales como «la noche es azul» (pág. 270); «el silencio sonoro» (pág. 261), que decoran su búsqueda íntima. Abomina de las pedagogías absurdas y apela, del mismo modo que la novela jarnesiana, a la búsqueda de la felicidad, el gran tema en definitiva de todas estas novelas gemelas:

Benditas todas las impresiones radiantes en las que hemos sido piratas... malditas la moral y la pedagogía absurdas que apresaron y volaron nuestros galeones cargados de oro! ¡Con lo hermoso que sería vivir acordes con nuestra vida! (pág. 262).

\section{Conclusión}

La narrativa lírica española incorpora algunas notas propias del género novelístico de formación como «intelectualización», metaficción, o estructura memorialística para ahormar una serie literaria que indaga en espacios colegiales opresivos. Quizás los ejemplos más representativos en época de plenitud novecentista sean A.M.D.G. de Pérez de Ayala y El jardín de los frailes de Azaña. Sin embargo, dos autores como Federico Carlos Sainz de Robles y Benjamín Jarnés aportan también sus contribuciones, como descendencia inmediata de esas dos novelas de internado.

En estas obras continuadoras de la serie se evocan los años de aprendizaje de sus autores en la institución educativa del seminario. Jarnés lleva a la plenitud el subgénero y lo hace fundiendo magistralmente el género de novela de formación en los moldes de la novela lírica, iniciados por Azorín. En El convidado de papel el autor aragonés aprovecha el esquema del Bildungsroman, en su modalidad de novela de artista, entendido como artefacto literario cargado de posibilidades para la comprensión de la naturaleza humana por medio de un exigente ejercicio literario ${ }^{43}$. El resultado es el de una novela de vanguardia, fundida conscientemente en la base humanística que nutre a toda la obra jarnesiana ${ }^{44}$.

${ }^{43} \mathrm{M}$. Beddow, The Fiction of Humanity. The Bildungsroman from Wieland to Thomas Mann, Cambridge University Press, 1982, pág. 5.

${ }^{44}$ R. Gullón, «Benjamín Jarnés», Ínsula, 46, 1949, pág. 8. Este crítico ya había señalado cómo la obra de Jarnés está puesta siempre al servicio del hombre, en la medida que su autor se muestra alejado de posiciones individualistas de «torre de marfil». J. Gracia, por su parte, 
El héroe Julio Aznar se construye una educación en la que, como dictan las marcas del género, participan como coadyuvantes y oponentes las instancias académicas habituales. Los profesores clérigos del seminario funcionan, al modo habitual en las novelas de internados, como personaje colectivo oponente. La anecdótica escolar queda voluntariamente reducida, puesto que el autor quiere alejarse del realismo, aunque no de la realidad, la cual es aprehendida en sus matices a través de una nueva mirada lírica, que se convierte en última instancia en «elemento conformador de la narración», por encima incluso del inequívoco hilo conductor autobiográfico que recorre este y los otros textos jarnesianos ${ }^{45}$.

Federico Carlos Sainz de Robles se siente impelido por las mismas fechas que Jarnés a hacer también su particular ajuste de cuentas con los años adolescentes de seminario, y avanza por la senda de la composición de estampas colegiales con una fuerza expresiva traducida en la descripción expresionista y otros recursos comunes a los escritores que novelan experiencias similares. Como en la novela de Jarnés, y las de los otros grandes escritores, tampoco está ausente la impugnación de los modos pedagógicos antinaturales, representados en el personaje profesoral colectivo que integra el claustro del seminario. Pero donde el autor se muestra verdaderamente eficaz, más incluso que esos otros escritores mayor calidad que redactan sus memorias adolescentes, es en la recreación realista de la anecdótica escolar (Sainz de Robles es más galdosiano que joyceano).

Como en El convidado de papel, Sainz de Robles desarrolla el componente artístico, en tanto que el protagonista vive su religiosidad con una pasión que se proyecta en su entrega a la poesía. De modo que los rasgos genéricos del modelo Bildungsroman en su versión de Künstlerroman también se hacen aquí evidentes: edad juvenil, meta formativa, dificultades en el camino, mentores y proceso de autorreflexión que empuja al sujeto lírico a escribir. Aunque quiera hacer todo ello transitando por las novedosas maneras narrativas de novela lírica y dramatizada e intente flexibilizar los materiales novelísticos al modo de Jarnés, Mario en el foso de los leones acusa por aquí alguna insuficiencia por falta de acción y exceso verbal.

caracteriza la novelística jarnesiana como «prosa de ideas»: J. Gracia, «Fuera de foco: la prosa de ideas de Jarnés», Ínsula, 673, 2003, págs. 12-13.

${ }^{45}$ E. Zuleta, Arte y vida, pág. 145. 